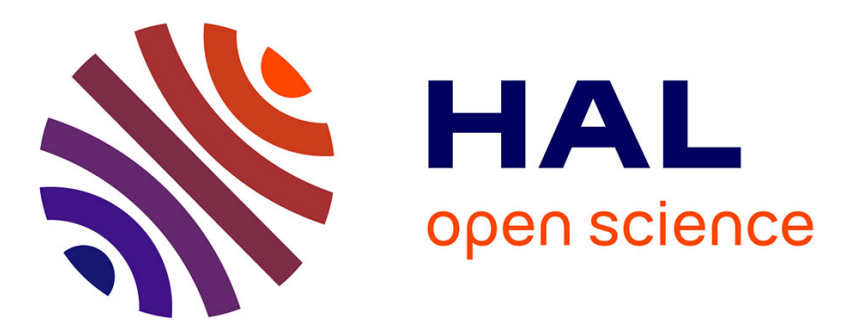

\title{
Biopharmaceutical entrepreneurship in two Japanese and French bioclusters: differences in founder profiles and experience
}

Eric Jolivet, Caroline Lanciano-Morandat, Hiroatsu Nohara, Daniel Pardo

\section{- To cite this version:}

Eric Jolivet, Caroline Lanciano-Morandat, Hiroatsu Nohara, Daniel Pardo. Biopharmaceutical entrepreneurship in two Japanese and French bioclusters: differences in founder profiles and experience. Asian Business and Management, 2009, 8 (4), pp.429-460. halshs-00424901

\section{HAL Id: halshs-00424901 https://shs.hal.science/halshs-00424901}

Submitted on 26 Nov 2011

HAL is a multi-disciplinary open access archive for the deposit and dissemination of scientific research documents, whether they are published or not. The documents may come from teaching and research institutions in France or abroad, or from public or private research centers.
L'archive ouverte pluridisciplinaire HAL, est destinée au dépôt et à la diffusion de documents scientifiques de niveau recherche, publiés ou non, émanant des établissements d'enseignement et de recherche français ou étrangers, des laboratoires publics ou privés. 


\section{Bio-pharmaceutical entrepreneurship in two Japanese and French bio- clusters: differences in founder's profiles and experience.}

$27^{\text {th }}$ of May 2009

Draft version - Please do not quote without permission of authors

*Eric Jolivet, University of Toulouse, Graduate School of Management (IAE), Research in Management Centre (CRM-CNRS), 2, rue Doyen Marty, 31042 Toulouse Cedex 09 France Eric.jolivet@iae-toulouse.fr

Caroline Lanciano, LEST-CNRS (UMR 6123), 35 avenue Jules Ferry 13100 Aix en Provence, France

Hiroatsu Nohara, LEST-CNRS (UMR 6123), 35 avenue Jules Ferry 13100 Aix en Provence, France

Daniel Pardo, LEST-CNRS (UMR 6123), 35 avenue Jules Ferry 13100 Aix en Provence, France

Paper submitted to Asian Business Management, Special Issue on Cultures Meet Technology 


\section{Abstract:}

Favoured by genetic engineering breakthroughs, a new type of firm has emerged in the pharmaceutical industry, called the New Biotechnology Firm (NBF). NBFs are 'bridging institutions' as they accelerate the commercialisation of science from academia to the pharmaceutical market and facilitate technological incursions into drug development or therapeutic paths yet unexplored and as such, have raised particular industrial and political interest around the world. Successes are, however, outstanding in the NBF world and some countries seem to offer much more favourable environments than others. Countries performances are usually benchmarked against their provision of favourable resources and institutions: patent rights, venture capital, dedicated stock market, skilled human resources. This paper takes an alternative route by considering the entrepreneurial side of NBF emergence: founders/entrepreneurs experience and incentives to create NBFs as a major factor of the emergence of these bridging institutions. To do so, 'entrepreneur's biographies' and their firm creation experience were collected in two comparable bio-clusters in France (Evry) and Japan (Kobe) on 11 Japanese and French drug development NBFs. The result shows an interesting variation in entrepreneurs' backgrounds and motivations across countries in that almost all of our French entrepreneurs came from public research institutes whereas a large share of our Japanese entrepreneurs came from large pharmaceutical companies. This finding questions the universal nature of entrepreneurship in bio-pharmaceutical firms and invites consideration for a model of entrepreneurship that is socially embedded in a country's specific institutional and historical factors.

Key words: High tech entrepreneurship; New Biotechnology Firm; Professions and careers; Innovation systems; Societal and institutional change; University-industry relations; International comparisons 


\section{Introduction}

The drug development business has experienced a tremendous transformation in the last 20 years. As this industry became gradually more concentrated around a handful of very large multinational pharmaceutical companies, the creative part of drug discovery was increasingly taken over by a new type of small bio-pharmaceutical firm, called a New Biotechnology Firm (NBF).

These 'science based' entrepreneurial ventures have been considered as an emerging hybrid organisational form between universities and large industrial companies, aimed at accelerating and diversifying the process of drug innovation. They are exploring and facilitating the transfer of new therapeutic paths and new compounds - based on biotechnologies - from prominent university researchers that invented them to the industry. They are novel intermediaries, or 'bridging institutions' between university research and large pharmaceutical companies (Gans and Stern 2003), and as such, now represent a major source of innovative drugs drugs (Cokburn and Henderson 1998).

Gene therapy, cell therapy, and tissue culture are amongst the promising new approaches to diseases — such as diabetes, HIV, cancers, cardio-vascular diseases or muscular dystrophy — explored by these start up firms that unsurprisingly attracted important economic and political interests around the world (Lehrer et al. 2004, Casper this Volume).

Most observations and analysis, so far, are based on the US experience where the NBFs model originated. The question of how this model was exported and adapted to different institutional contexts has recently attracted more attention (Gittelman 2006, Casper 2006). 
International comparisons have stressed important disparities between countries in terms of the speed it takes to adopt these 'bridging institutions', as well as the ability to generate such new forms of organisation. Specifically, despite their renowned academic research, Japan and France seem to be performing poorly (Lehrer et al. 2004, Kneller 2007, Ernst and Young 2007).

Explanations for these disparities have generally been found in the more or less favourable environments provided. A number of ingredients have been considered necessary for growing NBFs with success. Advancement of academic research, favourable intellectual property, maturity of the national venture capital industry, and the existence of a dedicated stock market are amongst the ingredients found crucial by many experts (Kortum et al. 2000, Mustar 2001; Casper 2006).

In this paper, we would like to take a new angle to compare country-level differences, one that would stress the role of NBF entrepreneurship sources and incentives as a major discrimination factor between countries.

Relying on the national innovation system framework (Freeman 1987), we claim that NBF, as bridging institutions, are embedded into specific national organisational arrangements that need consideration. Accordingly, different roles are played by universities, large and small pharmaceutical companies and start up companies in biomedical innovation depending on the country considered (Kneller 2007). In this perspective, NBF creation should be considered both as an entrepreneurial action and as an organisational and institutional rearrangement of the existing national innovation systems. Who are entrepreneurs and where do they come 
from? How do they capture technological opportunities? How do national contexts influence their profiles and careers?

So far, very limited comparative studies are available to support or discard this view and more empirical support is needed. This paper reports on such a study aiming at contributing to filling this knowledge gap. It explores the links between the relatively poor performance of Japan and France in terms of NBF creation in relation to the sources and incentives of NBF entrepreneurship. Therefore, we compared NBF entrepreneur's biographies, strategies, and motivations to create an NBF in the two countries and linked them to specific features of Japan and France national systems of innovation. National systems of innovation are defined as 'the networks of institutions in the public and private sectors whose activities and interactions initiate, import, modify, and diffuse new technologies' (Freeman 1987). More broadly, the perspective adopted consist in considering that the innovative performance of firms in a particular country, depend on the manner in which a variety of actors (small and large firms, educational and research institutions like universities and research institutes, customers) interact to create new knowledge and innovations. Japan was shown as a country enjoying a highly efficient innovation system based mainly on the integrative role of large private companies supported by strong industrial policies coordinated by MITI (Freeman 1987). France was described as a fairly centralised nation, organized around a major divide between basic research and technology development mainly promoted by public research institutes, and the commercial exploitation by national-champion type large companies (Chesnais 1993)

We sampled our NBF companies in two comparables clusters, Every near Paris, and Kobe, on Japan’s Midwestern coast. In depth interviews were conducted with 20 business founders in 
these two bio-clusters for a total sample of 11 companies. Additional data about the companies, in terms of the clusters and the respective national policies implemented in France and Japan during the period of observation, was collected for comparative purposes.

The profiles and entrepreneurs' experience in our Japan and France samples exhibit contrasting results and delineate identifiable careers in the two cases. It supports our claim that NBF creation be understood as one new organization finding its place in the wider existing national system of innovation.

The paper is divided in four main parts. The first part situates NBF in the literature and shows that NBF creation has become an issue of international country comparison. Introducing the national innovation perspective, we argue that entrepreneur's profile and experience are at the heart of country-specific new biomedical innovative arrangements. By profile we refer to human capital categories i.e. the background and professional experience. The second section describes the research methodology used in our research project, and describes both our sampling process in Japan and France and the variables we considered to characterise founders. Section three discloses the main findings of our research and compares NBF's entrepreneur's profiles and experience in our France and Japan samples. The contrasted results found and their implications are then discussed in the final part of the text. 


\section{I - Biotech Entrepreneurs in international perspective}

In this paper, we are focusing on biotech entrepreneurship in the field of drug and new therapy development. Although this share varies with countries, of the estimated 4203 biotechnology firm population in the world in 2005, roughly half are so-called 'red biotech', dedicated to the health sector (Ernst \& Young 2005). Among them, some are developing platform technologies and others are dedicated to drug discovery and new therapy (Casper 2006). Drug and therapy discovery oriented firms are intensively science-based, and are strategically of considerable importance to the pharmaceutical industry: while pharmaceutical R\&D experiences an historical loss of productivity, an estimated $20 \%$ of new drugs already come from these firms and experts anticipate they would reach 40\% by 2010 (Ernst \& Young 2006). They are representing crucial opportunities for large pharmaceutical firms worldwide.

The ways in which these opportunities were seized in different countries seems, however, to be very variable. In this section, we review and discuss the literature then propose an approach focusing on the sources of entrepreneurship, the knowledge capture mechanisms, as well as the motivations of entrepreneurs, all questions which are lacking comparative perspectives. 


\section{A) Biotech entrepreneurs as key figures in the new drug $R \& D$}

1) New Biotech firms as key players in the new pharmaceutical industry organisation

In the drug sector, as we have seen, a recent and striking occurrence has been the emergence of New Biotechnology Firms (Malerba et al. 2002). As large pharmaceutical firms’ R\&Dbased exploitation strategies seem to meet productivity limits, biotech startups propose new therapeutic approaches, more targeted drug design processes, and a new model for funding radical innovation (Galambos et al. 1998).

Many experts estimate that these NBFs represent a great creativity potential to renew aging large firms' portfolios and to explore unique and original technological paths efficiently. Some authors argue that NBFs are more efficient at the creativity part of drug discovery, whereas large pharmaceutical firms continue controlling the clinical, regulatory and marketing aspects (Cockburn et al. 1998).

In this respect, it is not surprising that NBFs have garnered so much attention on the part of policy makers who have tried to set favourable conditions for their emergence. Important institutional reforms have been undertaken such as University re-organization, Intellectual property laws changes, as well as thorough industrial policies encouraging business creation and academic spin off in the biomedical sector. Pharmaceutical firms and university researchers have equally been attracted by the opportunities offered. Most reflections on NBF are based on the US case, where this model emerged. Recently, several authors investigated the manner in which this model was adapted to a variety of institutional contexts (Ibata-Arens 2005, Gittelman 2006, Casper 2006, Kneller 2007). 


\section{2) Biotech entrepreneurship in international perspective}

Considerable investigations have been carried out in the last 20 years by academics to understand the specificities and key success factors of these knowledge-intensive firms, which are now quite well identified. As most of the NBF emergence occurred in the United States, particularly in a few well-endowed US areas such as California and Massachusetts, so too did academic investigations.

International comparative studies have been undertaken recently to pinpoint large disparities in country performances and ability to generate such new forms of organisations (Lehrer et al. 2004; Bozeman et al 2004, Kneller 2007, Ernst and Young 2005).

Common explanations for cross-country variability include: the density of networks relations between universities (Powell et al. 1996), NBF and large pharmaceutical companies (Cockburn et al. 1998, Kneller 2003), the presence of advanced research labs and star scientists (Zucker et al. 1998, 2002), to the development of venture capital and dedicated stock markets (Kortum et al. 2000, Mustar 2001) and the set up of a favourable IP rights (Kneller 2003). Such analysis tend however to assume little variety in NBF firms and benchmark mutatis mutandis NBF creation and growth rates against a high profile US model (Mangematin et al. 2003).

Interesting approaches have most recently emphasized the role and place of the country specific institutional contexts in which the NBF model was transferred as a significant 
variable explaining cross-country performance (Lehrer et al. 2004, Ibata-Arens 2005, Casper 2006, Gittleman 2006). For instance Casper, drawing on the theory of varieties of capitalism, has found that countries exhibiting liberal forms of capitalism (US/UK) offer more favourable environments to the emergence of biotech start up than Coordinated Market Economy forms (Germany/Japan) (Casper 2006). This research agenda suggests that international comparisons of NBF require in depth understanding of the specific institutional contexts in which they are located.

The national system of innovation theory (Freeman 1995) offers another interesting framework, we believe, to carry out this agenda as it aims at understanding 'major differences between countries in the ways in which they have organised and sustained the development, introduction, improvement and diffusion of new products and processes' (Freeman 1995 p.19). This theory pays particular attention to the respective and complementary role played by major actors contributing to innovation (universities, Government labs, large and small firms, and also end-users) in relation with country specific institutional contexts. This framework would fruitfully be applied to situate NBF creation in their wider societal contexts.

Close to this approach, one recent study has recently illustrated the variety of national arrangements in the biomedical field and the interest of articulating NBF organisations to country specific institutional arrangements (Kneller 2007). Carrying out such a welldocumented comparative study, Kneller (Kneller 2007) demonstrated that the sources of biomedical innovation were not similar in the US and Japan, as the interplay and complementarities of large pharmaceutical, universities and start up firms differ in these two contrasted institutional contexts. He found that large pharmaceutical companie's in-houseR\&D has been the major vessel in Japan's effort to appropriate biotechnologies, breaking 
away from the US model in which start ups and specially academic start ups have played the central role in biomedical progress (Kneller 2007).

3) The sources and incentives of NBF entrepreneurship

As Gompers and Lerner (2005) put it, there is now a large literature dealing with the success factors and the necessary resources for technology venture, but 'much less understanding of how these venture capital-backed entrepreneurs come to be entrepreneurs in the first place'. An additional question concerns the mechanisms through which scientific discoveries are transformed into valuable commodities.

In this paper, we consider NBF creation as an economic action 'embedded' in the wider societal context. Our argument comprises three main lines.

First, the mechanisms at play have a lot to do, we argue, with the uncertainty associated with NBF entrepreneurship and their perceived risks. Gompers and Lerner question of how and why some individuals venture into business creation even take a particular flavour considering how risky the business of NBF creation is (Pisano 2006). Why, then, would some individuals or group of individuals take a chance on running such a risky business? What are the incentives, positive or negative, leading them?

It is possible to distinguish between risks of three different natures. The collective and institutional management of these risks deeply conditions entrepreneurship.

1) There is a risk that we would call entrepreneurial, that is associated with the success or failure of the NBF and the subsequent loss or gain of personal capital involved. This is a 
function of the sort of commitment chosen by NBF founders: how much of their personal resources they have committed, how much ownership and control they retain in the firm, how much support they can get from their original organisation.

2) There is a risk that we would call strategic. An NBF is a bet, this bet can lead to a successful innovative product or not, or at least to a successful exit or not. The commercial future of bio-venture products are marked by dynamic uncertainty (Casamatta 2003) and NBFs exhibit high rates of turnover (Powell et al. 1996, Pisano 2006). Many small biotechnology firms actually prefer to focus on platform technologies or to offer services than position themselves in the drug and new therapy discovery competition. This strategic risk depends to a large extent on the national system of biomedical research and innovation, particularly on the sort of synergies that start up firms would find with larger established companies.

3) Finally, there is a career risk involved. Taking the lead or getting highly committed to one NBF might imply leaving a good safe position or not being as productive in ones original job. This risk relates to the rules and organisation of profession and careers in the biomedical sector.

Our second line of argument regards founders to bridge the two worlds of science and industry, and articulate them within their country specific system of innovation. As Kneller convincingly demonstrated, sources of biomedical progress and innovation vary across countries (Kneller 2007). Entrepreneur's origin should reflect such variations in national locus of biomedical innovations: in the US where research universities are prominent sources of biomedical innovations, academic entrepreneurship is most common (Shane 2004). Another complementary dimension associated with the locus of innovation regards knowledge 
capture mechanisms (Zucker et al. 1998). How do founders organise access to and obtain property rights over valuable biomedical knowledge? The nature of knowledge involved in new products and therapies together with the rules of its appropriation condition how business founders elaborate capture mechanisms linking their companies to these sources. Rare and tacit knowledge characteristics of biomedical discoveries led U.S. NBF to closely enroll the most prominent scientists in their research field - 'star scientists' - (Zucker et al. 1998).

The third line of argument relates to the peculiarities of the NBF activity. Start up creation requires a unique set of competence, strategic vision, and leadership to which no established career path generally prepares. So, the question of how entrepreneurs are recruited and trained is central as their competence extend to embrace a variety of heterogeneous dimensions. Entrepreneurs experience is thus an interesting variable to look at, as it should reflect how each particular country brings particular solutions to this problem.

As a bridging institution, NBF need to bring together the two worlds of university research and pharmaceutical industry. In the past, pharmaceutical companies would somehow deal directly with university professors and labs in a more or less formal way. To be economically justified, NBF need to improve and ease the translation between these two worlds, in a way that universities or large firms alone would not or could not do. One interesting view considers NBF as a more favourable organisational setting for academic inventors to apply their discovery into a commercial concept than would be possible at university (Lehrer et al. 2004). One key aspect relates to the creation of practicable career paths and labour markets. When such a market exists and is easily available, it provides an alternative for skilled people to industrial or administrative hierarchies and constitutes a source of independence and self achievement. 


\section{II - Research settings}

\section{a) sample}

This study evaluates the influence of entrepreneur's profiles and experience of company founders on the constitution of 11 NBF, 6 in France and 5 in Japan. This number being relatively small, we compared our data to larger national statistics on biomedical entrepreneurs in France and Japan to assess sample representativeness and the robustness of our results. General trends of our samples in terms of sources of innovation, origin of entrepreneur, performance of companies were confirmed to be very consistent with national data reported (JPO 2003, JBA 2005, 2006; France biotech 2007). More detailed discussion will be provided together with our results It was however difficult to find surveys detailed enough to provide global statistics on the origin and careers of NBF founders. In addition, both the institutional context and the industrial dynamics are quickly evolving in both countries in the biomedical sector. For instance, in Japan, strong emphasis was given to academic spin off in the last few years, and it will probably affect the balance of large company versus academic spin off in this country in the future.

Table 1 compares a number of general characteristics of Japan and France biotech fields showing that the two countries profiles are comparables.

[Table 1. overall picture of Japan and France biotech fields] 
France and Japan share a number of common characteristics: a rather strict distinction between public and private research and careers, an excellent public research but with limited knowledge transfer to firms and commercial outcomes, important implication of a central state in economic coordination, relatively weak SME sector as compared with performing large global firms.

France national system of innovation is historically characterized by importance of governmental labs and public research institutes as a major actor (Chesnay 1993). In addition to universities, governmental research centres and research institutes play a prominent role in research and notably basic research and technology development. The National Scientific Research Centre (CNRS) exemplifies this historical division between education and research oriented public organizations. In the biomedical fields, other public research institutes and governmental labs complement the CNRS (like the National Medical Research Institute 'INSERM', Pasteur Institute, Gustave Roussy Institute and even the National Atomic Energy Centre 'CEA' that developed some health related research programmes). Japan national system of innovation by contrast was structured around large companies integrating technological knowledge and creating technological knowledge through intensive in house R\&D and strong links with manufacturing (Freeman 1987).

The biotechnology 'sector' is made of very different realities and a wide variety of companies. For instance, its applications include products as different as cosmetics, seed and food, energy, drugs addressing fairly different markets. It was consequently our choice to focus our study on firms located in a similar industrial environment, namely biomedical start ups involved in drug discovery or new therapy development. We used a limited sample of firms for two reasons. First, considering our research objective to link NBF creation to the societal context, 
data quality and data collection on biographies of founders and their experience of creation required in-depth qualitative interviews. Some 50 interviews of about one hour and a half each were conducted in France and in Japan by the research team with founders but also with 'context actors’ such as policy makers, public lab researchers, local authority representatives, cluster representative, venture capitalists involved with our 11 NBF founders. Second, for comparison purposes and consistency of our sample, we restricted ourselves to firms directly involved in biopharmaceutical $R \& D$ activities competing in the same industry and found in two comparable clusters. They were identified in limited number in the two clusters (some 10\% of total firms) and a few of them did not reply to us.

All firms sampled are situated in the same human drug and therapeutic products industry and are virtual competitors. For confidentiality reasons, we do not use actual person or company names, but call them by codes (for French NBF FE1, FE2, FE3, for Japanese NBF JE1, JE2...). For instance, J1 licensed in F1 therapeutic innovation. NBF have developed in a large number of sectors as their new products innovation have been applied to agriculture, veterinary, environment, and human health. In addition, bio-clusters are populated with small firms providing bio-material, medical instruments, equipments, services or devices to drug development companies. Besides, only SME's with an entrepreneurial background and a strategic independence were included, excluding local affiliation and large company branches from our sample to retain only the ones with headquarters in our two clusters (Evry and Kobe). One exception is J3, which was created as a joint venture from a Japanese and an Australian NBF. Although R\&D cooperation was intense between the two entities, J3 remained autonomous enough to have its own business creation history, and we decided to keep it in the sample. Finally, all our firms were in their early stage of development at the time of the interview. Interviews were conducted by researchers experienced in qualitative studies. 
All firms selected come from two bio-clusters: the Evry bio-cluster located near Paris, France (Jolivet 2001) and the Kobe bio-cluster in the Kansai area, Japan (Jolivet 2007). These two clusters are of comparable size (about 70 companies in Evry and 100 in Kobe) and are both considered amongst the most prominent in their respective countries (regrouping roughly one company on ten), and focused on new therapy and new drug development. Both clusters benefitted from important public funding and support both at the national and at the local level.

\section{b) Data and measures}

A number of independent variables, making the identity card of our sampled companies are disclosed in table 2a for the French NBF and 1b for the Japanese ones.

Time of creation - The first important question regards the company year of creation. It is an important variable as regards the business creation and development of a company. Different phases of NBF development have been recognised to correspond to different needs in terms of human capital and resources: for example, in terms of financial counterparts, seed money, venture capital, investment banks usually succeed to one another (Casper 2006). Depending on the stage of maturity the NBF reaches, the focus of the company activity evolves from more scientific to more managerial (Bozeman et al. 2004, Murray 2004). A majority of new firms failing within their 3 first years of existence, surviving can already be considered an important achievement for NBF. Time not being precise enough to identify such phasing; we 
considered another related variable, the number of employees. Together, they are used as a rough indicator of growth and maturity.

In our study, we are interested in the influence of entrepreneurs in the very beginning of business creation. Date of creation is marking the very start of the NBF venture, a time of reference $T_{0}$. During our study, we discovered that if the date of creation is indeed important, as from then on the innovative project gets a real corporate body, and a business existence, the creation time might not exactly represent the same situation in each company: in particular, pre-entrepreneurial phase might be more or less extensive.

Technology and markets - The second set of variables we are considering are the technology used and the target 'markets' (in the pharmaceutical industry, the therapeutic classes). According to the literature, as we have seen, the very raison d'être of biopharmaceutical NBFs is to explore new paths and ways to approach drug development and diseases treatment. Together, technologies and markets are defining the arena for product competition.

In terms of technology, a common distinction concerns radical and incremental innovations as they are relying on different learning processes. Another distinguishes between product and process innovations. We found them difficult to apply here. The categorisation introduced by Casper (2006) between platform and discovery based biotech proved more operational in our study. We interpreted discovery based as covering our full sample of drug discovery and new therapy discovery companies. Indeed, these companies distinguish themselves by taking in charge the upstream creative part of the drug discovery process. By contrast, we considered as platform companies, firms with only activity in supplying materials or services to drug discovery ones. This has strategic implications for the firm: when they are discovery oriented, 
key factors of performance are a) leading the race to developing a new therapy and b) securing property rights to exploit this advantage commercially (Burton et al. 1999).

Target markets or diseases are the second important variable in this framework. Biopharmaceutical ventures apply their embodied knowledge in a yet unexplored way to the drug/new therapy innovation process, or to a new target. It means that a variety of combinations are possible for differentiation. NBF mastering the same technologies might apply them to different targets or therapeutic classes. Conversely, one disease could be approached through different angles based on different technologies and scientific knowledge. Although a certain consistency between technology-product-market is certainly important for success, we have observed some flexibility in that respect on the part of the companies. Several of them had opportunistic and flexible behaviours as regards the acquisition of a technological body of knowledge and they diversified after a few years of existence. On the other hand, several changed or extended the number of targeted diseases for one particular technological path during their development process. The tables below are listing the French and Japanese companies in our sample and their main characteristics.

[Table 1a - List of French NBF]

[Table 1b - List of Japanese NBF]

Table 1a and 1b show several elements. First, our sample is limited to 11 cases, which is relatively small. Justification for this choice is the important similarities of the firm studied in terms of technology, localisations and industry. All these factors have been demonstrated to be of influence on NBF studies (Stuart et al. 1999, Gompers et al. 2005). Our firms are 
operating in the same field and with comparable industrial and regulatory environments, which makes it easier to analyse and compare how each company proceeds to attract valuable resources and how it affects their performance. In other words, the limited number of records in our sample is counterbalanced we hope by the control of a number of induced bias that would have been introduced confirms the comparability of the French and the Japanese sampled firms.

\section{c) Variables}

This study investigates three main questions: who are the business creators and where do they come from? How do they capture scientific knowledge and embody it into a commercial commodity or intermediary? How does this vary across countries?

As we have seen, our comparative settings make it possible to compare our sampled French and Japanese companies ceteris paribus. In this section, we present the variables by which we will compare them.

\section{1) Entrepreneur's origin}

\section{1) Entrepreneur's origin}

For most observers as well as for policy makers, considering the 'science-based' nature of NBF, they are likely to be established by academic-entrepreneurs (Lehrer et al. 2004, Shane 2004). Inventors of scientific discoveries are indeed a natural source of NBF, as they might follow up their inventions to a more commercial stage. 
Another view to the origin of entrepreneurs stresses the role of large established companies (Burton et al. 2002). Even though the authors recognise that rates of new venture spawning vary amongst them, they argue that the competence and reputation effects granted by such firms provide an important social capital (i.e. network of relations) to employees willing to become entrepreneurs (Burton et al. 2002).

A third source of biotech ventures points to experienced entrepreneurs or entrepreneurial employees (Shane et al 2003). The San Diego cluster is a case in point (Casper 2007): it started with no tradition in commercial biotechnology and has become, after 27 years, one of the well established and recognised bio-clusters gathering some 120 NBF. The author argues that although the original biotech company Hybritech commercially failed, it actually served as a backbone in the establishment of a developing networks of experienced managers that later irrigated current successful companies (Casper 2007).

1.2) three categories of NBF entrepreneur's origin

From this, we retained three categories 1) academic-entrepreneurship 2) spin-off entrepreneurship (from large firms) 3) professional entrepreneurship (from other biotech firms).

\section{2) Knowledge capture mechanisms}

\section{1) knowledge source}

This is a most common view to consider university as the source of knowledge for NBF creation (Zucker et al. 1998, Shane 2004). The logic beyond this view stands in the assumed ‘science based' nature of NBF, science being naturally sourced at universities. The meticulous work of Kneller (Kneller 2007) demonstrated this view as too simplistic as the locus of 
biomedical innovation depends on country specific institutions: university centrality certainly holds in the US while large pharmaceutical and agro-food R\&D produced significant basic research in Japan (Kneller 2007). In addition, governmental labs (or public research institutes) might occupy a prominent place in certain countries like France (Pasteur Institute, Gustave Roussy Institute, the CNRS, the INSERM) or to a lesser extent Japan (Riken).

In our research, we are considering four categories of sources 1) Universities 2) Governmental Research Institute 3) Large pharmaceutical corporations R\&D 4) Other firms $\mathrm{R} \& \mathrm{D}$

2.2) knowledge capture: mobility and commitment

Knowledge source might be distinct from founder's origin and background: we have observed several cases in which the founder of the company had a background in business management and sourced its medical and biological knowledge from universities and research institutes. It conducts us to emphasize the role of 'knowledge transfers', or more precisely the mechanisms through which firms get and appropriate valuable knowledge.

There are two important characteristics of NBF knowledge base. First, as we are focusing our study on the creation stage of NBF, the knowledge base of the firm has to be sourced outside. Second, as we are talking of business firm commercialising novel products and therapies based on scientific and technological discoveries, valuable knowledge ought to be rare (small team of inventors), often tacit and difficult to transfer. This makes it excludable and appropriable (Zucker et al. 1998, 2002). One implication is that it often is embodied in the inventor and its close collaborators (Zucker et al. 1998). The question for firms is how to get an access to these people and their knowledge. 
One well identified knowledge capture mechanism is inventor based entrepreneurship. In this case, scientists or their close collaborator follow on their discoveries to a commercial stage (Mangematin et al. 2002). Personal competence and relations are then transformed into human and social capital for the firm through scientist mobility (Murray 2004).

Another capture mechanism consists in establishing collaborative ties with inventors. Direct training and contacts at bench level with inventors are considered as possible substitute to direct mobility (Zucker et al. 1998).

Zucker has pointed to another essential aspect of the question, that of the level and form of commitment (Zucker et al. 1998). This aspect is we believe very relevant as modalities of mobility of inventors, as well as the nature of collaborative ties pertains on NBF knowledge base. For instance, in the US, a strong correlation has been found between the personal involvement of star scientists and the most successful NBF (Zucker et al. 1998).

The following categories have been chosen 1) mobility of inventor 1a) complete mobility and leave from original institution 1b) part time mobility 2) status 2a) CEO 2b) CSO 2c) Board member 3) collaborative ties 3a) formal contracts 3b) informal links

2.3) knowledge appropriation: patenting and complementary assets

As we have just seen, the sort of knowledge base used by NBF is often rare, tacit and difficult to transfer in addition to be novel. This means that NBF might want to secure access to this knowledge and obtain some sort of exclusivity on its use is crucial in the perspective of future commercialisation. Patenting is considered an efficient appropriation mechanism in the pharmaceutical industry. Thus, patenting behaviour represents an interesting indication of firm strategy. 
In this study we retain the following categories 1) no patent 2) acquisition of original inventor's patent 3) acquisition of original inventor's patent and filed complementary patenting 4) portfolio acquisition and filing of complementary patenting.

3) Entrepreneur's profiles

\section{1) Entrepreneurs identity}

Stephan and Audretsch propose a career life cycle model in which the first part of the academic career is focused on building a scientific reputation, while the second part is aimed at exploiting this reputation, cashing in being one way to transform academic capital into financial capital. In a large firm with well defined career paths such as the Japanese firms uses (Aoki 1988), similar reflection should hold true. One implication is thus that the age of founder matter, as they are indicators of the type of individual career strategy they adopted while creating a company.

\section{2) competence depth or scientific expertise}

As we have seen, performance of the NBF depends in good part on knowledge capture mechanisms that will contribute to transform founders past experience into a firm capital Capturing such body of knowledge and capitalise it into a start up firms suggest that previous experience of the entrepreneur, particularly with related research activities plays a role (Murray 2004). One classical variable is certainly founder's scientific and technological education (both level engineer, $\mathrm{PhD}$ and field).

Another variable regards the experience and status gained in the academic field. Mangematin recalled the importance of founders experience (Mangematin et al. 2002). He introduces a distinction between junior scientists - scientific and technological specialists- and senior 
scientists - who gained more coordination and management skills. His results show that junior scientists tend to found category A firms - slow growth, local resources based, addressing local niche market- , while senior scientists rather establish category B firms -fast growth, attractive, research intensive, addressing broad market (Mangematin et al. 2002).

We retained the following variables

1) Education and status

(1a) M.Sc 1b) M.D 1.c) pharmacist 1.d) PhD 1.e) Post doc 1.f) researcher 1.g) Associate or full professor)

2) Experience

(2.a) junior researcher 2.b) senior researcher 3c) famous researcher (adapted from Mangematin et al. 2002)

3) accuracy discloses qualitative information on the field of expertise

\section{3) Competence visibility or signalling}

Strong uncertainty and asymmetries of information make it hard for external decision makers such as star scientist, venture capitalist, or fund providers to recognize the quality of the project of business creation. Entrepreneurs face the 'liability of newness': lack of resources, organization and reputation, uncertainty about the future. Reputation and centrality in networks condition access to resources in conditions of high uncertainty (Zucker et al. 1992, Gompers et al. 2005).

Patenting and publishing activities are major mechanisms through which such as reputation and prestige is constructed (Stuart et al. 1999, Burton et al. 1999). They are also a part of academic high level know how: publishing and, to a lesser extent, patenting require highly skilled people and are part of the unique competences brought to start up by well trained scientists. 
Visibility is part of the firm strategic positioning (Mangematin et al. 2002): the reputation of famous researchers plays a positive role for firm B - high profile, research intensive, fast growth- to attract resources, but no significant correlation was found with firm A.

\section{4) competence breadth or managerial expertise}

In science based firms, scientific and technological expertise certainly is essential. The specificity of NBF though is to combine such high level scientific knowledge with qualified business and management ones. In science based venture, such as NBF's, establishing the right human capital depend on the entrepreneur own skills and competence, but also on his/her ability to make the right choice in terms of internal/external hiring of complementary people, on his relations and reputation to attract resources (Burton et al. 2002). Managerial skills, strategic skills and credibility can be acquired through specific experience in the pharmaceutical or the biomedical start ups firms.

We retained

1) Education

(1a) Master of business 1b) MBA)

2) Professional experience i.e career

(a) researcher 2b) senior manager 2c) top manager 3) accuracy - discloses qualitative information about the industry).

\section{4) NBF performance}

One important aspect regards the comparative performance of NBF firms. As we noticed, evaluation of NBF at early stage is difficult, especially before IPO or buy out that will set a valuation process to them. 
Several studies have identified date of creation (Gompers et al. 2005), size (Burton et al. 1999), alliances, and cumulated level of investment (Stuart et al. 1999, Shane et al. 2003) as relevant indicators of performance before IPO or buy-out. Although they might follow several strategies, the most research intensive NBF have been found to have no sales, as they are involved in early stage development of drug or therapies (Mangematin et al. 2002). 


\section{III - Preliminary results}

In the following section, we disclose preliminary results from our comparative research of bio-business ventures in Evry and Kobe bio-clusters. We particularly focused on what we are calling 'Entrepreneurs profiles and experience', a set of variables described in section II.

[Table 3a - French 'Entrepreneurs profiles']

Our sample confirms Mustar's view (Mustar 2001) on the predominance of academic entrepreneurship in France. This result is also consistent with Mangematin's observations (Mangematin et al. 2002).

Government labs source and academic entrepreneurship

Our French entrepreneurs have on average graduated as pharmacists or medical doctors and then pursued their studies through a PhD in immunology or molecular biology in one of the French prestigious research institutions such as Institut Pasteur, Institut Gustave Roussy, or Institut Cochin. The competence depth of these entrepreneurs is very high. They have been trained for years as accomplished researchers and could both accumulate skills such as designing, executing and signalling advanced research programmes, and get an overview of world state of art and opportunities through years of research and exchange in the scientific community.

After years of research and skills embodiment, they recognized that they control reasonably well a piece of unique or rare knowledge that could be transformed into novel technology and 
therapy. They radically alter their career path to become start up CEO and develop their idea into a commercial product.

Scientific knowledge is then accumulated and embodied by individual researchers in public labs and then transferred with the mobility of these individuals as entrepreneurs of the start up firms. This strong commitment goes with a profound influence of the inventor on the company organization and strategy. This modality of transfer, strongly anchored in our sample, seem rather outstanding as it leaves aside all other mechanisms of knowledge transfer such as technology transfer through contracts, or senior scientists affiliation to start ups (two exceptions are F2 and F4).

Moving senior researchers enjoyed favourable conditions from their public researcher institutions to either acquire patents or exclusive licences to their inventions. Based on this constituted core technology at start up establishment, limited further publishing of patenting were observed in our sample. Patenting and publishing activities indicate different types of firm behaviours and types. Most firms in our sample patented one proprietary process and then limit their publishing and IP activities to developing potential applications to downstream value their invention. The limited role of ties kept with the original laboratory is another striking observation. Most of the companies in our sample switched to downstream networks of research including clinical trial hospitals, patient associations and more generally, research allies that would contribute to validate their therapeutic new paths. F2 provides an exception, in that all remains very much linked to public research labs.

Globally, the breadth of entrepreneur's competence is relatively limited to scientific activities, with very little experience in the industry. Most of them had years of management experience 
as academics: they have been team leaders, programme or laboratory directors, and more rarely hospital managers. Compared with other public labs fellows, our academic entrepreneurs are characterised by two specificities: most of them had long exposure (through post doc usually) to US/UK prominent universities; and to other French or Foreign NBF.

Taking a more detailed look at the population of founders, two distinct categories are observed: one classical academic career with people founding a companies between 55 and 65 years old. This seems consistent with the career life cycle model (Audretsch et al. 1999). According to this model, after they have built a successful academic career, embodied unique cutting edge knowledge and experience on valuable technologies, they are aiming at cashing in during the second half of their career (Audretsch et al. 1999). A second modality of this career strategy is made of short cutting academic and biotech career with people in their forties

[Table 3b - Japanese 'Entrepreneurs profiles']

In our Japanese NBF, pharmacist-managers-entrepreneurs are ruling. In our sample, the importance of the large diversified firm and the Japanese labour market is really observable. This confirms Kneller study on the role of large pharmaceutical and agrofood R\&D in Japan biomedical innovation (Kneller 2007). Our results are also consistent with available statistics: $57 \%$ have their source in large industrial companies, $39 \%$ from universities or governmental labs (JBA 2004). 
Knowledge source in our Japanese sample emanates from three different origins. University based knowledge certainly plays a role in three of the five companies (J5,J2,J1). But by contrast with the French case, this is not the only source of Japanese NBF technology. On the 5 firms in our sample, two are direct spin-off from large firms R\&D (J1, J4). Finally, one company in our sample sources its technology mainly from foreign NBFs (J3).

In our sample only one firm was founded clearly as a university start up (JE5). Only one entrepreneur (FE5) was also the inventor of the core technology that was exploited in his company. All other firms have been established by experienced managers with strong pharmaceutical experience. Large companies such as Kanebo, Santen, Sumitomo, Ajinomoto, Fujisawa involved in exploring biotechnologies within important research programs directly or through joint ventures framed their professional experience deeply.

Our Japanese entrepreneurs have on average graduated from the best universities, private or national, and acquired good educations in science. Most of them are pharmacists or medical doctors, and sometimes obtained a PhD. Brilliant students, they then were hired by prominent large Japanese companies, most often starting as industrial researcher and gradually gaining more managerial responsibilities and know how. Only J2 and J5 are based on prominent university scientist affiliation and only J5 was founded by a scientist-entrepreneur.

Most of the founders have been trained for years as research / development directors or senior managers, a place at which they could get a good sense of the specificities of the drug development innovation process from concept to market, as well as an accurate knowledge about the quality, quantity and cost of resources required to do so. Finally, during years of management they learned organizing skills, both on how to efficiently interact with others and 
efficiently organize working environment. Most could develop their expertise in recognising good opportunities in terms of drug seed and get used to thinking of technologies and projects in terms of a portfolio. More than incorporating frontier science themselves, they have learned to recognise it in others, and evaluate which one would represent a promising product candidate for the future.

In cases sourced in pharmaceutical or large agro-food firm R\&D, licensing or buy out of the property rights occurred in parallel with the large company taking a shareholder participation in the spin off. The start up firm continued patenting complementary aspects of the technology (compounds, process, targets), and published further in this area.

Two firms (J2 and J5) are based on the more classical university knowledge sources. However, they differ from their French counterparts in their knowledge capture processes. Japanese scholars did not alter their university career path. They rather seized an additional possibility to 'cash out', to value the knowledge and know how they had accumulated. And indeed, J2 and J5 are based on transfer from 4 university scholars, all of whom continued publishing and continued basic research at university after business creation. None of them left their academic jobs.

So the resulting start up firms are places of intermediation between the academic and the industrial world, in which the knowledge transfer mechanism relies centrally on organizing a relevant division of labour with part time academics transferring their knowledge and an industrial drug development team. Complementarities include involvement of academics in publishing, co-patenting and further researching while managers of the start up take care of product development, industrial application and commercial transactions. These start-up firms 
are in all cases administrated by professional managers, working as some kind of 'business coach’ of the academic researchers from which they capture the core technology.

The performance of our Japanese companies is impressive: most of them are following a fast growth trajectory with a large financial support. Most of them envisioned IPO as a mid term exit.

Sampled companies are 4 years old, in average younger than our French sample (5 years old). In terms of performance it means that we should expect that the French sample exhibits larger companies, with more important funds rose. Actually, the reverse is true. Average employees for the French sample is 15, and 29 for the Japanese sample, which is a considerable size difference, of almost double growth.

In terms of funding patterns, most Japanese firms received grants or subsidies from the Government as their French counterpart, important differences are visible in the allocation of money to early start ups by private firms. While only two French companies had raised private venture capital funds, all Japanese companies had done so. For spin off firms, seed money and participation of the mother large firm favoured this cumulative virtuous circle. Most of our Japanese companies had some large pharmaceutical or first generation biotech as shareholders. Capital rose ranked from 500000 euros for the smallest, to 27 million euros. If we except JE5, Japanese companies rose between 10 million to 27 million euros (while the most effective fund raising firm in the French sample only reached 8 million euros) in 2007.

Finally, most companies in our sample have developed very robust strategic alliances. Conversely to most French firms, they first kept very strong ties with their knowledge 
sourcing institutions: spin off firms kept strong links with their mother firm (J1, J4, J3), and Start up firms with their originating universities. Most of them also established links with Competing NBF abroad. Finally, as was the case of France, companies developing innovative new science based therapies established links with university/ hospital/ patients organizations for clinical trial and application purposes (J2, J5).

These two trajectories are both really dominating in our Kobe/ Evry comparison, and at the same time are closely connected to the differences between the two countries' national systems of innovation.

[Table 4_- Summary table - comparative analysis of Japanese and French NBF]

The result of this investigation confirmed that NBF entrepreneurship follows important variations depending on the country considered. In our France sample, almost all of the entrepreneurs were found to be 'academic entrepreneurs'--a term used in regards to senior scientists who left their public research positions to take the lead of the start-ups they founded. By contrast, in our Japan sample, company foundation came from two sources: previous managers of the pharmaceutical industry, and academics. Strikingly, in Japan no university researcher left his/her public position to become an academic entrepreneur, and leadership of the firm was exerted by experienced industrial managers.

In our sample, sources of entrepreneurship vary strongly from one sample to the other, as does the knowledge capture mechanisms used: founders do not have the same experience and do not create the same kind of organisation. 
These differences invite us to articulate individual behaviours of entrepreneurs in the wider national system of innovation in which they take place. More specifically, it refers to barriers and incentives to bio-business creation in the two countries. In other words, the construction of 'bio-entrepreneurs' are embedded in wider societal elements (Lanciano et al. 1992). The nature of the institutional gap between university and industry (Lehrer and al. 2004, Gittelman 2006), and the emergence of a novel organisation to build a bridge between them, follows a very country specific path.

\section{IV - Discussion and conclusion}

There is a large consensus that New Biotechnology Firm creation represents an important challenge for country innovativeness, specifically in the biomedical field (Ibata-Arens 2005). International comparative studies are still scarce, and many of them share a common assumption that countries performance in this respect should be benchmarked against the US model where NBF entrepreneurship originated (Ernst and Young 2005). Recently, pioneering work have pointed that NBF creation is part of a wider institutional picture that need to be considered for comparison purposes (Lehrer et al 2004, Casper 2006, Gittelman 2006, Kneller 2007). In addition, very limited data and studies are available to date to pursue this ambitious research agenda.

Our research objective is to contribute to this research programme by deepening our understanding of NBF entrepreneurship in Japan and France. Against the US benchmark, Japan and France have been classified as poorly performing in taking advantage of the new biotechnology paradigm. Our study invites to somewhat more elaborated and longer term analysis as it confirms that NBF creation is not a universal or stand alone economic action, 
but one that is deeply embedded in a wider national system of innovation. Comparisons mutatis mutandis of rates of creation thus require more in depth understanding in order to be properly interpreted. Although through a limited number of cases, the comparison we made already clearly indicates that NBF 'entrepreneurs' in France do not have the same background, experience and motivation as their Japanese counterparts. Beyond our samples, available data and statistics suggest that these results should hold true at country level. Our findings reflect many very differences pointing to two crucial elements in understanding NBF creation: -the organisation of professions and careers in the biomedical field (Lanciano et alii 1992), -the organisation of national systems of biomedical research and innovation (Kneller 2007).

In this final section, we would like to come back on two main findings and discuss their interpretation and implications.

In this paper, we have presented the result of a comparative study performed about drug discovery start up firms in Kobe, Japan and Evry, France. Representativity of our sample needs to be confirmed in the future and certainly be established on a larger scale, although available statistics from French and Japanese Biotech Trade Associations are consistent with our samples. In addition recent studies seem to confirm the observed trends: the importance of academic entrepreneurship in France and the comparative weight of large companies spin-offs in Japan (Ibata-Arens 2005; Mustar 2001), as well as important institutional and incentive obstacle to academic mobility (Motohashi 2004).The results clearly indicates that biographies of entrepreneurs and business creation experience exhibits very contrasted patterns in Japan and France. 
French academic-entrepreneurs were ‘cashing in’ years of public research discoveries. In the interviews, several of them considered that NBF constituted the right vehicle to do so, as compared with their original research institutes or universities.

As Lehrer et al. (2004) described, they are enjoying a full consistent organisation to help them push their discovery into a practical cure or compound. Their model of commitment is then very important and they usually took the lead of the NBF and left their position in the public sector. Since 1999 - and the law on innovation- in France, the career risk associated with this behaviour is relatively limited as they could return to their public research position in case of failure.

This pattern conveys several implications at a national/ industrial level. First, the performances of the NBF are limited, especially as regards growth and employment. This is consistent with observations that academic start ups grow more slowly than others (Audretsch and Stephan 1999). Second, as a bridging institution with the organisational role of feeding large pharmaceutical companies portfolios, this pattern might also bear some limits due in part to its focus on academic competences.

Japanese entrepreneurs exhibit a hybrid model. One key finding is the limited commitment university professors took in all but one case. So one question naturally follows: would professors in Japan show a more limited interest in 'cashing in' than their US counterparts? Or would they be less interested than French researchers in having an NBF as an organisational vehicle to apply their discoveries into practical compound or cure? This is doubtful. 
The Japanese government has considerably reformed the academic and national university status in recent years to favour the creation of NBF by academics. For instance, since 2000, like in France, Japan's academics are officially authorised to take part in a commercial activity without losing their jobs. One workable line of explanation could be that of acceptability and professional norms. Life time employment and very close social control are important features of Japanese organisations (Lehrer et al. 2004). In addition to the legal contract, academics are bound by more informal mutual commitment with their peers, as these peers control academic careers (Lehrer et al. 2004). How well would individual initiatives of cashing-in be perceived by other academic members? How acceptable would it be for peers that one of them spends its time for private rather than collective purposes?

A second key finding is the importance of founders coming from pharmaceutical companies. This is really unexpected, as most of the literature and policy making, including in Japan, are stressing academic entrepreneurship as a major target (in Japan, the Government targeted 1000 such academic bio-ventures by 2010 according to Lehrer et al. 2004). We see two main lines of analysis of this finding.

One is consistent with Burton et al (2002) idea that large organisations generate their own competition. This idea applies here. After years of considerable profits and relative industrial stability during which they importantly invested in R-D projects and bio-technology transfer from the US, Japanese pharmaceutical industry has reorganised deeply and divested. For some Japanese managers this meant a break in the lifetime employment model and/or important opportunities to buy promising projects for cheap prices. In our sample, this has been a major motivation and source of NBF creation. 
The other refers to the larger societal context of Japan, and the role of large corporations in the Japanese economy (Lehrer et al. 2004). In a recent analysis, Kneller (2007) has shown that large pharmaceutical companies have largely orchestrated the transfer of emerging US biotechnologies to their internal R-D in an 'autarkic' manner i.e. as the central integrative organization of innovation. This is consistent with the appropriation mechanisms of technology long observed in Japan (Lanciano et al 1992) and more widely consistent with observations made earlier about Japan NIS (Freeman 1987). Thus, the very important presence of large pharmaceutical company managers in NBF creation might well be the Japanese way of appropriating biotechnology and constructing entrepreneurship.

This pattern of entrepreneurship in turn has implications at the national level. First, the low involvement of academics in business creation might well limit the opportunities for NBF creation from university discoveries, which are considered by many as a rich source of drug discovery firms. On this side, some important changes are on-going, and the situation might evolve in the future. Second, the strong presence of large pharmaceutical managers should ease the establishment of strong links with them. Our samples seem to indicate this, as several such companies have benefited from investments by their 'mother' companies. On the other hand, a recent study by Kneller (2007) points to the relative weakness of the ties between large pharmaceutical firms and Japanese biotech start ups. Further investigations seem necessary to clarify this point.

It is our understanding that 'entrepreneurs' are shaped by long lasting societal dimensions. In this regard, we believe, this paper contributes to departing from a unique and universal view about 'NBF entrepreneurs' as a simple extension of the US case. If this finding is convincing 
enough, it then is an invitation for further and more systematic research on the societal shaping of NBF entrepreneurial activities. 


\section{References}

Almeida, Paul and Bruce Kogut (1997) 'The exploration of technological diversity and the geographic localization of innovation’ Small Business Economics, 9, 21-31.

Audretsch, David, B. and Paula, E. Stephan (1996) 'Company-scientist locational links: the case of biotechnology’ American Economic Review, 86, 3, 641-652.

Audretsch, David, B., and Paula, E., Stephan (1999) 'Knowledge spillovers in biotechnology: sources and incentives’ Journal of Evolutionary Economics, 9, 97-107.

Bozeman, Barry, and Vincent Mangementin (2004) 'Editor’s introduction: building and deploying scientific and technical capital’ Research Policy, 33, 4, 565-568.

Burton, Diane, Jesper, Sorensen and Christine Beckman (2002) 'Coming from good stock: career histories and new venture formation’ Social Structure and Organizations Revisited, 19, 229-262.

Casamatta, Catherine (2003) 'Financing and advising: optimal financial contracts with venture capitalists’ The Journal of Finance, 58, 5, 2059-2086. 
Casper, Steven (2006) 'Exporting the Silicon Valley to Europe: how useful is comparative institutional theory’ in Hage, Jerald and Marius, Meeus (eds) Innovation, Science, and Institutional Change. A research handbook. Oxford UP. Pp 482-504.

Casper, Steven (2007) 'How do clusters emerge and become sustainable ? Social network formation and inter-firm mobility within the San Diego biotechnology cluster’ Research Policy, 36, 438-455.

Chesnay, F. (1993) 'The French National System of Innovation’ in Nelson, R. (ed) National Innovation Systems. Oxford University Press.

Ernst and Young (2005) Beyond borders. Global Biotechnology report 2005. Ernst and Young.

France Biotech (2007) Panorama 2006 of the biotechnologies industry in France (in French). France Biotech, Paris

Freeman, Christopher (1987) Technology policy and economic performance: lessons from Japan. Pinter

Freeman, Christopher (1995) ‘National Systems of Innovation in historical perspective’ Cambrige Journal of Economics, 19, 5-24.

Gans, Joshua, S., and Scott, Stern (2003) 'The product market and the market for 'ideas': commercialisation strategies for technology entrepreneurs’ Research Policy, 32, 333-350. 
Galambos, Louis, and Jeffrey, L. Sturchio (1998) 'Pharmaceutical firms and the transition to biotechnology: a study in strategic innovation’ Business History Review, 72, 2, 250-278

Gittleman, Michelle (2006) 'National Institutions, public-private knowledge flows, and innovation performance: a comparative study of the biotechnology industry in the US and France’ Research Policy, 35, 1052-1068

Gompers, Paul, Josh, Lerner and David Scharfstein (2005) 'Entrepreneurial Spawning: public corporations and the genesis of new ventures, 1986 to 1999’ The Journal of Finance, 60, 2, 577-614.

Hellmann, Thomas and Manju Puri (2002) 'Venture capital and the professionalization of start-up Firms: empirical evidence’ The Journal of Finance, 57, 1, 169-197.

Ibata-Arens, Kathryn (2005) Innovation and Entrepreneurship in Japan: Politics, Organizations and High Technology Firms. Cambridge UP.

Japan Bioindustry Association (2005) Bioventures statistics investigation report in Japan. JBA Tokyo

Japan Bioindustry Association (2007) Bioventures statistics investigation report in Japan (in Japanese). JBA Tokyo 
Jolivet, Eric (2001) ‘Evry’s Genopole, France’ a case study for the EU Eurolabs project, EU DG research. Unpublished document.

Jolivet, Eric (2007) ‘the Kobe bio-cluster, Japan’ report to the IBRI, Kobe, Japan. Unpublished document.

Kortum, Samuel and Josh, Lerner (2000) 'Assessing the contribution of venture capital to innovation’ The Rand Journal of Economics, 31, 4, 674-692.

Kneller, Robert (2003) 'Autarkic drug discovery in Japanese pharmaceutical companies: insights into national differences in industrial innovation’ Research Policy, 32, 10, 1805-1827.

Kneller, Robert (2007) Bridging Islands. Venture companies and the future of Japanese and American Industry. Oxford UP.

Lanciano, Caroline, Marc Maurice, Hiroastu Nohara, and Jean-Jacques Silvestre (1992) 'Innovation, acteurs, organisations : les ingénieurs et la dynamique de l'entreprise’ Working Paper, LEST-CNRS, Aix-en-Provence.

Lehrer, Mark, Kazuhiro, Asakawa (2004) 'Rethinking the public sector: idiosyncrasies of biotechnology commercialisation as motors of national R-D reform in Germany and Japan’ Research Policy, 33, 6-7, 921-938

Lerner, Josh, Merges, Robert, P. (1998) 'The control of strategic alliances: an empirical analysis of the biotechnology industry’ Journal of Industrial Economics, 46, 2, 125-156 
Malerba, Franco, Orsenigo, Luigi (2002) 'Innovation and market structure in the dynamics of the pharmaceutical industry and biotechnology: towards a history-friendly model’ Industrial and Corporate Change, 11, 4, 667-703.

Mangematin, Vincent, Stéphane Lemarié, Jean-Pierre Boissin, David Catherine, Frédéric Corolleur, Roger Coronini, Michel Trommetter (2003) 'Development of SMEs and heterogeneity of trajectories : the case of biotechnology in France’ Research Policy, 32, 621638.

Mustar, Philippe (2001) 'Spin-offs from public research: trends and outlook’ STI-Review, 26, 165-172.

Murray, Fiona (2004) 'The role of academic inventors in entrepreneurial firms: sharing the laboratory life’ Research Policy, 33, 4, 643-659.

Pisano, Gary, P. (2006) ‘Can Science be a business? Lessons from Biotech’ Harvard Business Review, 84, 10, 114-125.

Powell, Walter, W., Kenneth, W., Koput and Laurel, Smith-Doerr (1996) ‘Interorganizational collaboration and the locus of innovation: networks of learning in biotechnology’ Administrative Science Quarterly, 41, 116-145.

Shane, Scott (2004) Academic entrepreneurship. University spinoffs ans wealth creation. Edward Elgar 
Shane, Scott and Khurana, Rakesh (2003) 'Bringing individuals back in: the effects of career experience on new firm founding’ Industrial and Corporate Change, 12, 3, 519-543

Zucker, Lynne G., Michael, R. Darby, Marilynn, B. Brewer (1998) ‘Intellectual human capital and the birth of US biotechnology entreprises’ American Economic Review, 88, 1, 290-306

Zucker, Lynne G., Michael, R. Darby (2001) ,Capturing technological opportunity via Japan’s star scientists: evidence from Japanese firm's biotech patents and products’ Journal of Technology Transfer, 26, 37-58.

Zucker, Lynne, G., Michael, R. Darby, Jeff S. Armstrong (2002) 'Commercializing knowledge: University science, knowledge capture, and firm performance in biotechnology’ Management Science, 48, 1, 138-153 
9680 words

27 of May 2009 
Table 1: Overall picture of Japan and France biotech fields

\begin{tabular}{|l|l|l|l|}
\hline 2006 & US & JAPAN & FRANCE \\
\hline Number of biotech & 1452 & 586 & 420 \\
\hline Number of biomedical & - & 250 & 172 \\
\hline Number of public Cies & 336 & 12 & 11 \\
\hline Av. size & 89 & 16 & 9 \\
\hline Share of R\&D staff & - & 44 & 68 \\
\hline
\end{tabular}

Source: JBA 2005, 2007; France-biotech 2007 
Table 2a: List of French NBF

\begin{tabular}{|c|c|c|c|c|}
\hline Name & $\begin{array}{l}\text { Date of } \\
\text { creation }\end{array}$ & Technology & Target & $\begin{array}{l}\text { Number of } \\
\text { employee }\end{array}$ \\
\hline F1 & 2001 & Cell therapy & Urology & 20 \\
\hline F2 & 2006 & Cell therapy & HIV & 6 \\
\hline F3 & 2000 & $\begin{array}{l}\text { molecular biology and } \\
\text { diagnostic, target } \\
\text { identification }\end{array}$ & $\begin{array}{l}\text { Obesity, Diabetes, } \\
\text { schizophrenia, } \\
\text { autism }\end{array}$ & 34 \\
\hline F4 & 1999 & Monoclonal Antibody & $\begin{array}{l}\text { Cancer (pancreas, } \\
\text { liver) }\end{array}$ & 20 \\
\hline F5 & 2002 & $\begin{array}{l}\text { molecular biology and } \\
\text { diagnostic }\end{array}$ & $\begin{array}{l}\text { Cancer, } \\
\text { Orphan genetic } \\
\text { diseases }\end{array}$ & 8 \\
\hline F6 & 2004 & $\begin{array}{l}\text { Immunology, } \\
\text { proteomics } \\
\text { genetic engineering }\end{array}$ & $\begin{array}{l}\text { Functional animal } \\
\text { models }\end{array}$ & 7 \\
\hline
\end{tabular}


Table 2b: List of Japanese NBF

\begin{tabular}{|c|c|c|c|c|}
\hline Name & $\begin{array}{l}\text { Date of } \\
\text { creation }\end{array}$ & Technology & Target & $\begin{array}{l}\text { Number of } \\
\text { employee }\end{array}$ \\
\hline $\mathrm{J} 1$ & 2000 & $\begin{array}{l}\text { Gene therapy, } \\
\text { molecular biology }\end{array}$ & $\begin{array}{l}\text { CNS stroke } \\
\text { regeneration, } \\
\text { head Cancer }\end{array}$ & 30 \\
\hline $\mathrm{J} 2$ & $2005(2000)$ & tissue engineering & $\begin{array}{l}\text { Corneal tissue, } \\
\text { bone regeneration }\end{array}$ & 33 \\
\hline J3 & 2002 & $\begin{array}{l}\text { Cell therapy } \\
\text { tissue engineering }\end{array}$ & $\begin{array}{l}\text { Diabetes, } \\
\text { muscular } \\
\text { dystrophy, } \\
\text { myocardial and } \\
\text { cerebral infarcts. }\end{array}$ & 25 \\
\hline $\mathrm{J} 4$ & 2003 & $\begin{array}{l}\text { Gene therapy, } \\
\text { proteomics }\end{array}$ & $\begin{array}{l}\text { (Drug Targets) } \\
\text { cancer, arthritis, } \\
\text { dermatitis }\end{array}$ & 45 \\
\hline J5 & 2003 & $\begin{array}{l}\text { Recombinant vaccine, } \\
\text { gene therapy }\end{array}$ & Cancer & 12 \\
\hline
\end{tabular}


Table 3a: French 'Entrepreneurs Profiles’

\begin{tabular}{|c|c|c|c|c|c|c|c|c|c|c|}
\hline \multicolumn{4}{|c|}{ Identity } & \multicolumn{3}{|c|}{ Competence Depth } & \multicolumn{2}{|c|}{ Competence } & \multicolumn{2}{|c|}{ Competence breadth } \\
\hline $\mathrm{Na}$ & age & sexe & status & Education & Experience & accuracy & publishing & patenting & pharma & biotech \\
\hline F1 & 55 & M & $\begin{array}{l}\text { CEO } \\
\text { then } \\
\text { CSO }\end{array}$ & $\begin{array}{l}\text { Med. D. } \\
\text { Post doc } \\
\text { Researcher } \\
\text { Lab. Dir }\end{array}$ & $\begin{array}{l}\text { Senior } \\
\text { researcher }\end{array}$ & $\begin{array}{l}\text { Muscle cell } \\
\text { biol. } \\
\text { Published } \\
\text { Linked }\end{array}$ & $\mathrm{X}$ & $\begin{array}{l}\text { Patented } \\
\text { (Proprietary } \\
\text { process) }\end{array}$ & $\mathrm{X}$ & $\mathrm{X}$ \\
\hline F2 & 65 & $\mathrm{M}$ & CSO & $\begin{array}{l}\text { Med D. } \\
\text { PhD biol } \\
\text { Post Doc } \\
\text { Assistant } \\
\text { MCF } \\
\text { Lab Dir. } \\
\text { Dpt Dir. }\end{array}$ & $\begin{array}{l}\text { Senior } \\
\text { researcher } \\
\text { with 1st } \\
\text { rank } \\
\text { internation } \\
\text { al } \\
\text { publication } \\
\text { s }\end{array}$ & $\begin{array}{l}\text { Protein/P } \\
\text { Interaction } \\
\text { Mol. Biol., } \\
\text { Mol. Vir. } \\
\text { Published } \\
\text { large number } \\
\text { Quality } \\
\text { linked }\end{array}$ & $\begin{array}{l}\text { Large } \\
\text { Publishing } \\
\text { going on (on } \\
\text { new therapy/ } \\
\text { application) }\end{array}$ & $\begin{array}{l}\text { Patented } \\
\text { +In- } \\
\text { Licensing } \\
\text { from allied } \\
\text { lab } \\
\text { (proprietary } \\
\text { molecule/ } \\
\text { targets) }\end{array}$ & $\mathrm{X}$ & $\begin{array}{l}\text { Serial } \\
\text { entrepreneur }\end{array}$ \\
\hline F3 & 45 & $\mathrm{M}$ & $\mathrm{CSO}$ & $\begin{array}{l}\text { PhD Biol } \\
\text { Post docs } \\
\text { Team } \\
\text { leader }\end{array}$ & $\begin{array}{l}\text { Senior } \\
\text { researcher }\end{array}$ & $\begin{array}{l}\text { Diabetes, } \\
\text { Genomics } \\
\text { Published } \\
\text { little } \\
\text { Partially } \\
\text { linked }\end{array}$ & $\begin{array}{l}\text { Little } \\
\text { Publishing } \\
\text { (on } \\
\text { application) }\end{array}$ & $\begin{array}{l}\text { Patenting } \\
\text { portfolio } \\
\text { (proprietary } \\
\text { process)+ } \\
\text { in \& out- } \\
\text { licensing } \\
\text { (gene } \\
\text { targets) }\end{array}$ & $\mathrm{X}$ & $\begin{array}{l}\text { Serial } \\
\text { researcher }\end{array}$ \\
\hline F4 & 65 & $\mathrm{M}$ & CEO & $\begin{array}{l}\text { Pharmacist } \\
\mathrm{PhD}\end{array}$ & Researcher & $\begin{array}{l}\text { Immunology } \\
\text { Monoclonal } \\
\text { Antibody }\end{array}$ & $\begin{array}{l}\text { publishing } \\
\text { on new } \\
\text { technological } \\
\text { path/ therapy }\end{array}$ & $\begin{array}{l}\text { Patenting } \\
\text { portfolio } \\
\text { (proprietary } \\
\text { process)+ } \\
\text { patenting+ } \\
\text { in-licensing } \\
\text { (on specific } \\
\text { applications }\end{array}$ & $\begin{array}{l}\text { Hospital } \\
\text { Consultant } \\
\text { Senior } \\
\text { manager } \\
\text { Prominent } \\
\text { Company }\end{array}$ & Entrepreneur \\
\hline
\end{tabular}




\begin{tabular}{|c|c|c|c|c|c|c|c|c|c|c|}
\hline & & & & & & & & ) & & \\
\hline F5 & 40 & $\mathrm{M}$ & $\begin{array}{l}\text { CEO } \\
\text { CSO }\end{array}$ & $\begin{array}{l}\text { PhD Biol. } \\
\text { Post doc }\end{array}$ & Researcher & $\begin{array}{l}\text { Biosensors } \\
\text { Mol. Biol. }\end{array}$ & $\mathrm{X}$ & $\begin{array}{l}\text { Patented } \\
\text { (proprietary } \\
\text { process) } \\
\text { +in- } \\
\text { licensing } \\
\text { (on specific } \\
\text { disease } \\
\text { application) }\end{array}$ & $\mathrm{X}$ & $\begin{array}{l}\text { Serial } \\
\text { researcher }\end{array}$ \\
\hline F6 & 40 & $\mathrm{M}$ & CEO & $\begin{array}{l}\text { Med.D } \\
\text { PhD } \\
\text { Post doc } \\
\text { Researcher }\end{array}$ & $\begin{array}{l}\text { Senior } \\
\text { Researcher }\end{array}$ & $\begin{array}{l}\text { Immunology } \\
\text { Biol. Mol. } \\
\text { Cancer res. } \\
\text { Published } \\
\text { quality } \\
\text { linked }\end{array}$ & $\mathrm{X}$ & $\begin{array}{l}\text { Unpatented } \\
\text { (proprietary } \\
\text { process) }\end{array}$ & Hospital & $\mathrm{X}$ \\
\hline
\end{tabular}

Caption for Table 3a: French 'Entrepreneurs Profiles':

Source: interviews and firm documentation 
Table 3b: Japanese 'Entrepreneurs Profiles’

\begin{tabular}{|c|c|c|c|c|c|c|c|c|c|c|}
\hline \multicolumn{4}{|c|}{ Identity } & \multicolumn{3}{|c|}{ Competence Depth } & \multicolumn{2}{|c|}{ Competence visibility } & \multicolumn{2}{|c|}{ Competence breadth } \\
\hline Name & Age & sex & status & Education & $\begin{array}{l}\text { Experienc } \\
\text { e }\end{array}$ & Accuracy & publishing & patenting & Pharma & biotech \\
\hline J1 & 57 & $\mathrm{M}$ & CEO & $\begin{array}{l}\text { Pharmacist } \\
\text { PhD bio } \\
\text { Post doc } \\
\text { Associate }\end{array}$ & $\begin{array}{l}\text { Senior } \\
\text { Researche } \\
\text { r }\end{array}$ & $\begin{array}{l}\text { DNA } \\
\text { replicatio } \\
\mathrm{n} \\
\text { Cancer } \\
\text { research } \\
\text { Published } \\
\text { Linked }\end{array}$ & $\begin{array}{l}\text { Little } \\
\text { Publishing } \\
\text { (on new } \\
\text { therapy/ } \\
\text { application)+ } \\
\text { scientist } \\
\text { publishing at } \\
\text { university }\end{array}$ & $\begin{array}{l}\text { Buy + } \\
\text { patenting } \\
\text { portfolio } \\
\text { (proprietary } \\
\text { molecule, } \\
\text { targets, } \\
\text { process) }\end{array}$ & $\begin{array}{l}\text { Research } \\
\text { Director } \\
\text { Dept }\end{array}$ & $\mathrm{X}$ \\
\hline $\mathrm{J} 2$ & 46 & $\mathrm{M}$ & CEO & $\begin{array}{l}\text { Pharmacist } \\
\text { PhD } \\
\text { Researcher }\end{array}$ & $\begin{array}{l}\text { Researche } \\
\text { r }\end{array}$ & $\begin{array}{l}\text { Cell } \\
\text { Differenti } \\
\text { ation } \\
\text { Enzymol. }\end{array}$ & $\begin{array}{l}\text { X } \\
\text { Scientist } \\
\text { publishing at } \\
\text { their } \\
\text { universities }\end{array}$ & $\begin{array}{l}\text { Co-patenting } \\
\text { portfolio } \\
\text { (tissue } \\
\text { engineering } \\
\text { process) }\end{array}$ & $\begin{array}{l}\text { Research } \\
\text { Development } \\
\text { Senior } \\
\text { management }\end{array}$ & $\begin{array}{l}\text { Researcher } \\
\text { VC director } \\
\text { Serial } \\
\text { entrepreneur }\end{array}$ \\
\hline J3 & 60 & $\mathrm{M}$ & $\begin{array}{l}\text { CEO } \\
\text { Pdt }\end{array}$ & Pharmacist & $\mathrm{X}$ & $\mathrm{X}$ & $\begin{array}{l}\text { Little } \\
\text { publishing }\end{array}$ & $\begin{array}{l}\text { In-licenced } \\
\text { portfolio } \\
\text { mother bio- } \\
\text { venture } \\
\text { platform } \\
\text { (proprietary } \\
\text { cell } \\
\text { engineering } \\
\text { process)+ in } \\
\text { licencing } \\
\text { (cell } \\
\text { engineering } \\
\text { process) }\end{array}$ & $\begin{array}{l}\text { Patents, legal } \\
\text { Management } \\
\text { Senior } \\
\text { manager }\end{array}$ & $\begin{array}{l}\text { Senior } \\
\text { manager }\end{array}$ \\
\hline $\mathrm{J} 4$ & 51 & $\mathrm{M}$ & $\begin{array}{l}\text { CEO } \\
\text { Pdt }\end{array}$ & $\begin{array}{l}\text { Master } \\
\text { chemistry }\end{array}$ & $\mathrm{X}$ & $\begin{array}{l}\text { Med. } \\
\text { Chem } \\
\text { Published } \\
\text { Linked }\end{array}$ & $\begin{array}{l}\text { Publishing } \\
\text { (on new } \\
\text { therapy/ } \\
\text { application) }\end{array}$ & $\begin{array}{l}\text { Buy+Patenti } \\
\text { ng portfolio } \\
\text { (proprietary } \\
\text { molecule / } \\
\text { target) }\end{array}$ & $\begin{array}{l}\text { R\&D } \\
\text { Director }\end{array}$ & $\mathrm{X}$ \\
\hline
\end{tabular}




\begin{tabular}{|c|c|c|c|c|c|c|c|c|c|c|}
\hline J5 & 50 & $\mathrm{M}$ & Board & $\begin{array}{l}\text { M. D. } \\
\text { PhD } \\
\text { Post Doc } \\
\text { Associate } \\
\text { Professor }\end{array}$ & $\begin{array}{l}\text { Famous } \\
\text { researcher }\end{array}$ & $\begin{array}{l}\text { Gene } \\
\text { therapy } \\
\text { Published }\end{array}$ & $\begin{array}{l}\text { X } \\
\text { Scientists } \\
\text { publishing at } \\
\text { their } \\
\text { university } \\
\text { (on novel } \\
\text { therapy } \\
\text { application) }\end{array}$ & $\begin{array}{l}\text { Co-Patenting } \\
\text { (molecule/ } \\
\text { therapy } \\
\text { process) }\end{array}$ & $\mathrm{X}$ & $\mathrm{X}$ \\
\hline
\end{tabular}

Caption for Table 3b: Japanese 'Entrepreneurs Profiles'

Source: interviews and firm documentation 
Table 4 - Summary - comparative analysis of Japanese and French NBF

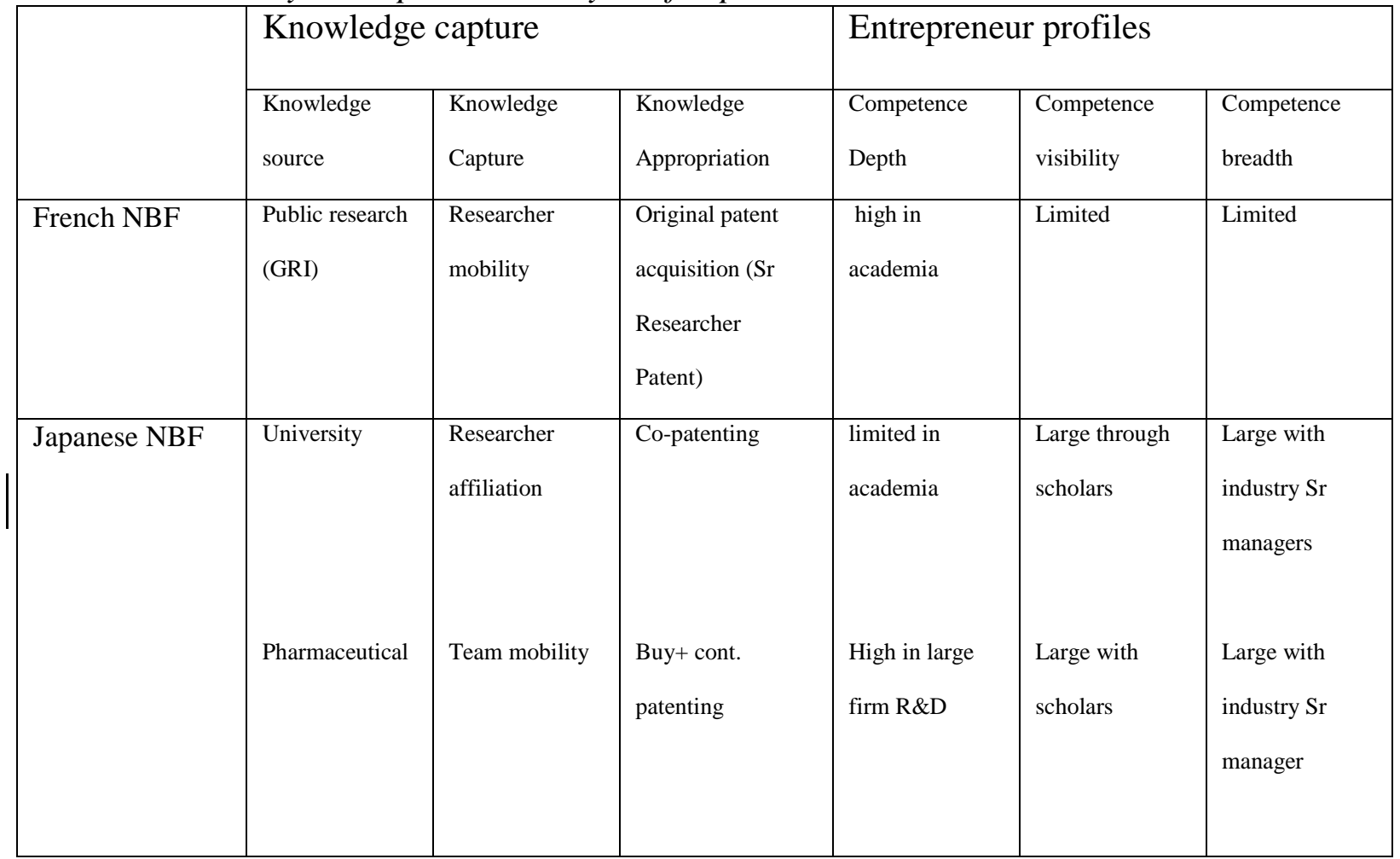

Caption for Summary - Comparative analysis of Japanese and French NBF Source: interview and firm documentation 